\title{
15
}

\section{On-the-Ground Tensions with Chinese Traders in Papua New Guinea}

\author{
Patrick Matbob
}

\section{Introduction}

Papua New Guinea (PNG) became the first country in the South Pacific to sign on to China's Belt and Road Initiative (BRI) in June 2018. Former prime minister Peter O'Neill's decision to join the BRI was no doubt driven by his desire for PNG to benefit from China's offer of funding and development opportunities. China's aid has less restrictive conditions than are usually required by PNG's traditional donor Australia, and is seen as attractive despite criticisms and warnings about the risk of falling into China's alleged debt-trap diplomacy (Mantesso 2018). O'Neill rebutted his critics, saying that PNG, like Australia and other countries, wanted to do business with China, the fastest-growing world economic power. O'Neill argued that PNG should have the choice to access China's markets, technology and financing for infrastructure development, reflecting one of the key points of the Blue Pacific approach to development endorsed by Pacific Island Forum (PIF) leaders in 2017. Secretary General of the PIF Dame Meg Taylor has also rejected the dominant narrative in the Pacific region that presents the Pacific nations a choice between traditional donors and the China alternative. Instead, she says that the PIF seeks genuine partnerships with all actors, including China (Taylor 2019). Geopolitics in the Pacific region is largely a matter for those in power, especially in 
developing countries like PNG. Generally, the people have little say, as the majority are isolated from the major commercial and administrative centres of PNG and affected by increasing poverty and a lack of basic government services. They have little knowledge or concern about PNG's foreign relations, except when they become affected by issues such as the spillover from the West Papuan independence struggle with Indonesia. The country's citizens remain largely spectators to the government's international relationships and dealings.

However, with O'Neill's resignation as prime minister and the election of his former finance minister James Marape as the new prime minister in May 2019, the country's focus has shifted somewhat. Marape is focusing internally with an agenda to fight corruption and ensure his people benefit fairly from their resources, part of his vision to 'take back PNG' and make it 'the richest Black Christian Nation on earth' (Kenneth 2019). Marape has so far kept his word by setting up a commission of inquiry into the UBS loan issue and reactivating the parliamentary Public Accounts Committee to inquire into the operations of government bodies. The inquiry into the AU $\$ 1.2$ billion loan from Swiss bank UBS is to determine whether PNG leaders, including former prime minister Peter O'Neill and current Prime Minister James Marape, broke the law when acquiring the loan. Marape has not deviated from PNG's foreign affairs policy of 'friends to all, enemies to none' and has welcomed all investors into the country as long as they follow PNG laws-and there will be no favourites, China included. It would be reassuring for many who are wary about PNG's relationship with China that Marape's first international engagement a month after taking office was to visit Australia to reaffirm ties with its former coloniser and seek funding assistance. Australia has since agreed to loan PNG US $\$ 300$ million (K1 billion) in direct budget assistance to cover its expenses and planned reforms, though details of the loan have not been revealed. Australia denied that the loan was to stop PNG accepting a loan from China. PNG, however, has formal ties with China and the fruits of the relationship are visible on the ground with a number of large infrastructure projects, such as roads, stadiums, conference centres and institutions, as well as China's biggest investment project in the Pacific, the US\$800 million Ramu Nickel project. The BRI is the latest initiative in this relationship.

PNG's interactions with China, however, have a long history. Contact began as early as the 15th century with traders hunting birds of paradise and continued when Chinese labourers were brought in to work on 
German plantations in 1884. There was a small number of Chinese traders who came and settled around that time, and their numbers and businesses grew over the years, spreading to other towns in PNG. When PNG gained independence in 1975, most of the Chinese took the option of Australian citizenship and moved to Australia. After that, the 'new Chinese', mainly from Malaysia, Indonesia and Singapore, as well as mainland China, began to arrive in PNG. While it is difficult to know exactly how many Chinese are in PNG, the number is generally estimated at around 20,000 (Chin 2008). The Malaysian Chinese were initially associated mainly with the logging industry, but some later became engaged in the retail industry throughout the country.

Other Chinese citizens in PNG are associated with companies like the Ramu Nickel mine and the infrastructure projects aid from China is funding in the country. These Chinese workers are usually flown into PNG to work on the projects and flown out again. Little is known about the arrangements the Chinese corporations have with the workers they bring into PNG. In a court case I attended in Madang, a Chinese construction company worker was charged with dangerous driving that caused the death of his Papua New Guinean passenger. He pleaded with the court to reconsider imposing a fine on him. He told the court that his employer was remitting his pay to his family in China and he therefore was not in a position to compensate the relatives of the victim. Whether PNG's signing on to the BRI will translate into increased engagement between PNG and China remains to be seen.

Countries like Australia and the US are concerned that PNG signing on to the BRI could place the country at risk of debt-trap diplomacy. Broadly defined, debt-trap diplomacy is where a creditor country intentionally lends excessive credit to a smaller debtor country with the intention of extracting economic or political concessions when the smaller country cannot service the loan (Doherty 2019). Yet, there are more pressing issues for PNG to address at home that may impact its future and stability. PNG's unstable political, economic and social situation, its chronic law and order problems and its widespread corruption in all levels of government pose the biggest challenges to its development aspirations. These problems will have an impact on whatever relationships PNG establishes at both regional and international levels. While Australian aid to PNG has mainly concentrated on building the capacity of the country's human resources and strengthening its governance system, China's aid has been geared towards building infrastructure. Politicians favour 
infrastructure developments as they are more visible and easier to quantify, adding to their portfolio of achievements during their term in parliament. Yet infrastructure development in PNG has its own challenges, including the country's unstable geography, the fact that almost 90 per cent of land remains under customary ownership and a lack of capacity and resources within the government systems to facilitate and process any government plans. In addition, PNG's problems with governance, especially at the subnational level, continue to hinder the effective implementation of projects as well as the delivery of government services to communities in rural areas of the country.

This chapter demonstrates that PNG's internal challenges continue to impact any planned development, creating tensions among the government, developers, landowners and other stakeholders. While the national government and politicians may engage with foreign investors and sign agreements for development projects at the national level, these investments are often stalled and delayed by the government's own incapacity to push the process forward through the bureaucracy at national or subnational levels. If the projects involve landowners, which they often do, that creates another layer of challenge that has to be negotiated, which can further delay and stall investments. Even agreements between project developers, the national government and the landowners made in the past need to be reviewed over periods of time, which can create added tensions. This chapter also details how Papua New Guineans are becoming increasingly aware of the issues created by foreign investments and agreements negotiated by their government and becoming vocally dissatisfied. An example is the PNG LNG project, which is yet to identify and compensate landowners, even though production and exports have commenced. Currently, the landowners of the Porgera and Ramu Nickel mines are demanding, with the support of their governors, that the mine agreements be reviewed. These issues create a complex environment for development in PNG and an unpredictable future for the planning and establishment of new projects. Marape's catchphrase of 'take back PNG' is already seen as an attempt to address these issues, particularly to ensure resource development has significant benefits for resource owners. The Marape Government's review of the new PNG LNG agreement is a move in this direction. 


\section{The new Chinese}

As PNG was moving towards independence in 1975, many of the 'old Chinese' who had been in New Guinea for nearly 100 years took the option of Australian citizenship and moved south because their future was uncertain in the emerging independent country. In June 1957, the Australian Government made a decision to give Asians who were born in New Guinea or arrived during the Mandated Territory of New Guinea years the opportunity to take up Australian citizenship (Sinclair 2006). The majority became Australian citizens while a few remained to become PNG citizens.

As PNG was moving towards independence, there was a general feeling of uneasiness and people did not know what the future would be like. Papua New Guineans were being prepared to take over jobs held by Australians and other expatriates and there was the expectation for indigenous people to run their own affairs. In Rabaul, where the majority of the Chinese population lived, the tensions created by land disputes between the Tolais and Europeans resulted in the killing of the district commissioner Jack Emmanuel (Goldring 1972), and the administration's introduction of the multiracial councils created fear amongst the Chinese population. There were also increasing law and order problems in parts of the country.

As the old Chinese were leaving along with other Australian and foreign expatriates, a new wave of Chinese migrants moved in to replace them. Chin (2008) categorises these 'new Chinese' into two groups: the Southeast Asian Chinese, who are ethnic Chinese from Malaysia, Indonesia and Singapore, and the mainland Chinese and Taiwanese.

The new Chinese migrants were also seeking economic opportunities, either to work and/or set up and operate their own businesses, or to expand their business empires, as in the case of the Malaysian timber merchants. The most successful of the timber merchants is Rimbunan Hijau, which has grown into a major diversified company. There has also been an increase in Chinese migrants from mainland China as PNG has looked north for aid and to attract Chinese investments in the country. A number of major Chinese state-owned enterprises have invested in PNG, mostly benefiting from China's 'boomerang' concessional loans that restrict the projects to the use of Chinese expertise, labour and equipment. Amongst the Chinese who have come from mainland China, Chin (2008) stated the largest number have done so under the work permit scheme. 
This scheme, which was designed to recruit expatriates with specific skills and expertise to be engaged by local companies to train locals workers, has been much abused. Instead, government officials are bribed and in turn have allowed in hundreds of Chinese workers with no skills or knowledge of the English language, an entry requirement under PNG law. Once in the country, these permit holders are employed in or set up small retail operations, mainly kai bars selling food, cheap electronic goods and clothing. A number of these operations have been busted by police and government officials and the owners convicted and deported. However, due to widespread corruption amongst migration officials_including law enforcement agencies-illegal migrants continue to come.

\section{It takes two to be corrupt, yet the Chinese get the bad name}

The large number of Chinese from mainland China who bribe their way into PNG and end up doing jobs reserved for Papua New Guineans are viewed with contempt by both fellow Chinese migrants and Papua New Guineans. They are blamed for giving all Chinese migrants a bad name. What is often overlooked is that it takes two parties to initiate a corrupt deal. This group of Chinese would never have set foot in PNG if PNG officials were doing their jobs honestly in the first place. After all, the migrants have to apply for visas and fulfil the requirements, then pass through customs and security checks before entering PNG. The fact that they are able to get visas from PNG officials while still in China proves that PNG officials are also corrupt and easily bribed to break the laws of the country. Yet when Chinese who are involved in any criminal activity or overstay their visas are caught, they appear in the PNG media as criminals who abused PNG laws. Nothing is said about the PNG officials who demand bribes and commissions who are also breaking the laws. They remain faceless and are not investigated or prosecuted for their crimes.

According to Chin, the mainland Chinese who bribe their way into PNG are poorly educated with limited skills and tend to become involved in businesses and employment reserved for local people. This brings them into daily direct contact with ordinary Papua New Guineans on the streets, so when the authorities finally catch up and deal with them, the bad news spreads. The majority of Papua New Guineans today were 
born well after independence and have had little or no experience of the good relationships that existed with the old Chinese; they form their views of the Chinese from the media and the popular views on the streets.

To add to the problem, the majority of Papua New Guineans do not distinguish the origins of the new Chinese and why they came to PNG. Instead, they identify the Chinese physically and culturally, not by their places of birth or nationalities. Therefore, the well-publicised wrongs of the Chinese who break the laws of the country are often used to judge the rest of the Chinese who are law abiding and innocent. The old Chinese in particular have been critical of the newcomers and have a poor regard for them (Smith 2014). Operating retail outlets has its risks and many Chinese shops, along with other local and expatriate businesses, have been targeted by criminals. The Chinese retailers who are driven by a desire to make a lot of money quickly place themselves at a higher risk because they tend to operate their shops longer hours into the evenings. Over the years, there have been numerous attacks on and killings of the Chinese in PNG, especially those involved in retail businesses. Many of the killings occurred in armed hold-ups by criminals, but some were by disgruntled employees who did not like how their bosses treated them. In 2013, the killing of four Chinese in their shop in Port Moresby made international news (BBC News 2013) and was condemned by then prime minister O'Neill. In Manus Province, the deaths of 10 Chinese retailers who were burnt in their supermarket was investigated by police and arrests were made after the matter was raised in parliament by the local member of parliament.

In a country of more than 800 languages, the names people give to a person or group of people can reveal a lot about how they are perceived. The recent poor relationships between the Chinese and the local people is revealed in the names the local people use to refer to them. In Tok Pisin, a Chinese would be called a Sainaman (Chinese man). If the Chinese person is disliked, they are usually referred to using derogatory names such as a Saiko or Kongkong. Kongkong (or Singapo) is also the common Tok Pisin name for the Chinese taro that originates from Asia. In his Melanesian pidgin dictionary, Mihalic says the Chinese object to being called Kongkong (1971). Saiko, on the other hand, is a more recent term used mainly to refer to the new Chinese. Its origin is uncertain, though, like other Tok Pisin words, it likely comes phonetically from the English word 'psycho', which refers to an insane person. 
PNG's vibrant media is also responsible for creating the negative perception of the Chinese over time, starting in the late 1970s and 1980s. Soon after independence, one of the major corruption cases investigated by the Ombudsman Commission and widely publicised in the media was the 1981 Diary Affair, which involved Singaporean businessman Tony Loh and the office of the then prime minister Sir Julius Chan (Ombudsman Commission 1982). In this case, officers within the prime minister's department had attempted, without following the due processes of going to a public tender or having funds budgeted, to buy 15,000 diaries from Loh's company for the government. The Central Supply and Tenders Board had three times rejected the application from the government to approve the purchase due to abuse of process, yet the government attempted to force the board's approval. In this case, government officers in the prime minister's department had prior contact and dealings with Loh and his company and thus wanted to give him the contract.

This was soon followed by the Barnett Inquiry, which investigated and reported widespread corrupt practices in the forestry industry involving PNG leaders and Asian businessmen of Chinese origin. The Barnett Inquiry (Barnett 1987) highlighted serious abuses of laws and practices that shook the forestry industry, particularly the use of transfer pricing, declarations of losses by logging companies to avoid paying taxes and the bribing of political leaders. Again, a prominent PNG political leader and public servants were involved. Many of the abuses remain today, and illegal logging continues with exports to China.

The Ramu Nickel project is a recent experience for Papua New Guineans of the way a large Chinese mining company has gone about trying to develop a mine in the country. Papua New Guineans have observed and experienced large mining projects such as Bougainville Copper Limited, Ok Tedi, Misima, Lihir and others where international standards of work practices on the project sites were followed by the companies when developing and operating the mines. The same was expected of the Ramu Nickel project, which began with Highlands Pacific at the exploration stages following the standards set in the country. However, when Highlands Pacific was not able to attract a developer due to low nickel prices at the time, the National Alliance Government of Somare went to the Chinese. It was a completely new experience for PNG learning how the Chinese develop a world-class project. The biggest initial shock was learning how the concessional loans would work, in that the Chinese were going to bring in their own workforce, plant and equipment, and there 
would be limited opportunities for the local workforce and suppliers to participate in the project. Locals with mining experience who managed to get a job with Ramu NiCo were further dismayed when they saw that the Chinese were not adhering to basic standards required in the operation of such a large-scale project. There were wide-ranging health, safety and pay issues that forced the Department of Labour and Industrial Relations to intervene and close down the project until all the basic requirements under the labour laws were met. The PNG Department of Labour and Industrial Relations issued a detailed list of recommendations in February 2010 for Ramu NiCo Management Limited and ENFI PNG Ltd to comply with.

Another major issue with the Ramu Nickel project was the abuse of PNG laws by allowing Chinese workers who could not speak a word of English or Tok Pisin and who had dubious 'expertise' to enter the country in large numbers. The Department of Labour intervened, arresting 178 illegal migrants and taking them to court. Eventually, then chief magistrate John Numapo found that the workers had not really 'broken' any laws because they were brought into the country under a special state-to-state agreement.

In an interview in 2007, then regional MP for Madang Sir Peter Barter urged the Chinese to understand the seriousness of the situation and begin to improve relations with landowners, the people and their employers:

They [the Chinese] need to improve their communication, employ responsible liaison officers, abide by labour and industrial laws, conduct regular briefings with the Madang and district administrators and to quickly begin initiating some services for the people. ${ }^{1}$

The latest issue affecting Ramu NiCo is the slurry spill at the Basamuk refinery, which became controversial when locals found dead fish in the area. A group of Swiss scientists independently engaged by the Madang Provincial Government investigated the spill, taking away and testing samples of the water and dead fish. They found toxic levels of heavy metal contamination and accused the company of not managing its waste properly. PNG's Conservation and Environmental Protection Authority said it had not authorised the study by the Swiss scientists and promised to carry out its own. A Provincial Government ban on the consumption

1 Sir Peter Barter, 15 February 2007. Regional member of Parliament for Madang. Madang. Interview with author. 
of any fish from the area until further tests created hardships for the local fishermen who depend on the sale of fish for their livelihood. The ban was eventually lifted in March 2020 when the Madang National Court declared it 'unenforceable' (PNG Report 2020).

Of course, not all Chinese companies operating in PNG performed as poorly as those that developed Ramu Nickel, and the Western mining companies also had their issues: the first Australian mine in Bougainville caused a civil war that took 20,000 lives; the Anglo-Australian Ok Tedi mine was responsible for polluting the Ok Tedi river; and the North American Porgera mine is still grappling with illegal miners and a host of other issues.

\section{PNG's chronic corruption and law and order issues remain a challenge for investors}

PNG has been plagued by rampant corruption for years now, with Transparency International's Corruption Perception Index 2018 placing the country at a low 138 out of 180 countries. Much has been said and written about the issue, which is widespread within the government from the national to the district levels. It is now seen as normal to bribe or pay commissions to get anything done. A lack of capacity, resources and funding has crippled government services, allowed corrupt practices to permeate all sectors of government and is visible and experienced everyday throughout the country. From parents bribing teachers to put their children in school to hospital staff stealing and selling medicines, policemen demanding fuel for their vehicles before they will attend to cases, politicians putting their own people in key government positions so they can divert funds and public servants colluding and misusing funds, the list goes on. The Public Accounts Committee, revived by Prime Minister Marape, held its first inquiry at the end of 2019 into the Department of Health. It found widespread corruption, a lack of accountability in the issuing of contracts to suppliers, officers getting bribes and unlawful appointments of persons to key management and administrative roles. While many political leaders have spoken out against corruption, none were as outspoken as the late former prime minister Sir Mekere Morauta. Sir Mekere, former governor of the Bank of PNG, said that when he was forced to resign in the 1990s, he detected serious signs of wear and tear and a weakening of the structures and processes of government: 


\begin{abstract}
Already a culture of political domination of all aspects of the state was developing, undermining the efficiency and profitability of state enterprises and the functioning of important institutions of the state whose independence formed a basic pillar of good governance (Morauta 2010).
\end{abstract}

The widespread corruption in PNG affects everyone, citizens and foreigners alike, and the Chinese are no exception. It can take the form of the bribes or commissions Chinese retailers pay to police or government officers to obtain protection from criminal elements, gain access to land, property or licences to operate a business or get quick services from government agencies. It can also take the form of paying kickbacks on the supply of equipment and services to government departments or state enterprises.

The PNG Government has strict laws that govern the use of public funds through the provincial and district treasuries. Yet politicians and administration heads continue to find ways to gain access to these funds illegally and do so without fear of being arrested and prosecuted.

After the anti-Asian riots in May 2009, the government at the time set up a parliamentary bipartisan committee to investigate their cause. The key government agency officers who appeared before the committee made revelations not only about the presence of illegal Asian migrants in the country, but that they were protected by top government officials and action could not be taken to deport them (Kolo 2009). Senior foreign affairs and immigration officers said there was 'rampart corruption and bribery' in their department, which was underfunded, understaffed and unable to do its job effectively (ibid.). The officers said they suspected that there were up to 15,000 foreigners living illegally in the country. The Philippines embassy revealed at the time that of the 10,120 Filipinos in PNG, 670 were permanent residents, 6,600 were temporary migrants and 2,850 were 'irregular or undocumented' (Hernandez 2009).

Today, the media continues to report on illegal foreigners who have been caught in the country. In 2017, the media reported four Chinese men had been arrested for illegally entering the country without proper visas. Another Chinese man arrested in Port Moresby after customs authorities discovered $\mathrm{K} 7$ million worth of illegal cigarettes being imported admitted to smuggling in a wide variety of goods, including guns, ammunitions, pornographic materials and drugs (Wani 2018). He also admitted bringing in duplicate documents such as blank bank savings cards, driving licences, work permits, passports and motor vehicle registration 
papers bearing duplicated model numbers. In a more sensational case, a Chinese businessman was arrested by police and charged with attempting to bribe police with K10,000 to stop ongoing investigations and release documents and items seized by police (Tlozec 2018). Police allegedly found the man in possession of 200 common seals belonging to various companies, including 24 owned by the Chinese Government. These companies included China Engineering (PNG) Ltd, China Railway Construction Engineering Group North Project Company PNG Ltd, China Harbour Engineering Company Ltd and Covec (PNG) Ltd, all of whom are working on major infrastructure projects.

Other activities revealed before the parliamentary committee included the booming guns for drugs trade, prostitution involving Asian women, foreigners entering the country illegally by land, sea and 'through the normal process', government agencies such as customs, foreign affairs and immigration lacking the human resources to do their jobs effectively, hundreds of millions of kina being lost through tax evasion, false declarations being made and companies hiding their books from authorities. PNG's Internal Revenue Commission admitted to the committee that it was only able to scrutinise 200 big companies, while the collection of tax from 6,000 smaller operations was unchecked. The committee also heard from customs that at least half or three-quarters of containers coming through the ports each week are unchecked, and that counterfeit and illegal products flood the country. Meanwhile, authorities said they cannot remove the cheap products sold on the streets because of the removal of the anti-dumping law. Unfortunately, the work of the committee ended inconclusively after the chairman, Anglimp-South Waghi MP Jamie Maxtone-Graham, and his deputy were removed by the government after he was accused of doing a radio talkback show about the inquiry while it was still in process and preempting its final report. Their removal prompted the resignation of three other members in protest: Theo Zurecnuoc (Finchhafen), then vice minister of public service Anthony Nene (Sohe) and Bulolo MP Sam Basil. Maxtone-Graham said he was removed because the committee was about to 'expose the involvement of certain politicians in questionable activities with certain people of Asian origin' (Tannos and Eroro 2009). In PNG, the political will and actions to match anticorruption rhetoric are all too often missing.

It is obvious that in order to attract investments and do business, PNG has to address the widespread corruption in government and business as well as minimise law and order problems. Unfortunately, PNG has not 
been able to effectively achieve this and genuine investors continue to take risks investing in the country and have to beef up their own security throughout their operations. Transparency International, when rating PNG and other Asia-Pacific countries on anticorruption, pointed out that one of the reasons for poor ratings is the overall weakening of democratic institutions and political rights. Investors, whether from China or any other country, have to negotiate the environment of corruption, law and order problems and a lack of effective governance when trying to do business in PNG.

\section{New Chinese and the retail industry}

Not all 'new Chinese' have entered PNG illegally; some have come legally and invested in the retail industry throughout the country. They have mainly taken over retail and wholesale businesses that belonged to the old Chinese and other expatriates and locals. In places like Madang, they have actually taken over recently built shopping complexes. The arrival of the new Chinese into the provinces has been received with mixed feelings by the indigenous people, with many expressing the view that the country's retail industry is again being dominated by the Chinese after seeing them depart in the years leading up to and after independence.

'Little by little they are taking slices of our businesses', says PNG activist Martyn Namorong, who campaigns to protect local jobs and communities. 'My people feel we can't compete' (South China Morning Post 2018). Despite their mixed feelings, many locals grudgingly admire the Chinese's strong work ethic and drive to make money. The Chinese also provide employment for many Papua New Guineans and contribute to the country's economy. In fact, a number of indigenous shop owners who had been struggling with their businesses, mainly due to cultural pressures from relatives and kinsmen to share their wealth, have gladly sold or rented out their businesses to the Chinese. The main disadvantage of the PNG wantok system (social security network), which is at the heart of the Melanesian cultures that promote communal values and tribal and family allegiance, is that it often works against indigenous businesspeople and prevents them from growing their businesses. While having large number of relatives and tribespeople can guarantee a businessperson cheap labour and security, he/she is expected to reciprocate by contributing to cultural feasts, ceremonies and funeral expenses and support the education and 
health of relatives. In the coastal areas of PNG, there is jealousy of people doing well in business. Businesspersons are always at risk of having their business assets sabotaged or, worse, being killed. Cultural obligations can affect the success of an enterprise and distract businesspeople from concentrating on their businesses as much as the Chinese would. In turn, local people admire and wonder how the Sainaman (Chinese) can sit in a shop from dawn to dusk, seven days a week.

This is not to say that doing retail business in PNG is easy for the Chinese and other expatriates. The risks are equally high for them, as one can see when visiting Chinese retail shops. The small shops on the street fronts are always vulnerable to criminal elements, and many have been held up and money and goods stolen. The Chinese have resorted to constructing steelgrid fences that enclose their shop fronts, sometimes with rolls of razor wire over the top. Grids are also sometimes built around the cash registers in the shops. Guards at the gates strictly control the crowds coming in or leaving with bags and body searches regularly take place. Body searches without authorisation are illegal under PNG criminal laws; however, people have come to accept the practice and often raise their arms above their heads in surrender when leaving the shops so body searches can be done quickly. But the guards are selective, allowing affluent customers to leave without body searches. There have been instances where guards have been assaulted for body searches, and there is at least one successful district court case against a Chinese shop owner in Wewak (Lapmiemben $v$ Kuso 2009). In addition to installing CCTV, the Chinese have come up with another way of preventing thefts. They build a raised platform, usually near the checkout, where they can have a bird's-eye view of the shop interior, and also of their checkout cashiers.

Obviously, the Chinese feel they can never trust anyone and are aware that much of the shoplifting is done with the aid of the shop assistants and/or security guards. To prevent this, the Chinese have identified the products targeted by shoplifters and these are sold over the counter in the front part of the shop, in full view of the shop supervisors and guards. One of the old Chinese retailers in Madang complained bitterly, saying she had stopped sponsoring local sports team and assisting the community because customers steal from her shop. Not long after, she began bringing in workers from Nepal to run the supermarket, thus creating a community of Nepalese in PNG. In an interesting twist, a new Chinese retailer who opened a shop in Madang has brought in checkout assistants from Misima Island in Milne Bay. Misima, a historic island that 
has had gold mine operations since 1900s, has three sizeable supermarkets in its small township, all operated by Chinese. These shops, which sell everything from groceries to electronics, fuel and hardware, were originally owned and run by locals. The Misima economy is largely supported by remittance from the island's workforce, many of whom were trained by Misima Mines in the 1980s and are working in other mining projects in PNG and internationally. Business there is brisk, especially during the end of the year when workers return to the island for Christmas to fulfil their cultural obligations. The Islanders are generally hardworking and reliable, and it seems the Chinese have recognised this.

The wide variety of cheap goods sold by the Chinese are often of poor quality. Many are imitation products of popular international brands, often with slight differences in the spellings of the brand names or in the logo designs that are hard to detect. Imitation products with popular international sports team brands abound, as do shirts with PNG's national colours, flags and souvenirs for independence and provincial days. In fact, in the past, one could not purchase the PNG national flag so easily, but today every Chinese shop has flags of all sizes ready for any occasion.

\section{Illicit trade poses the biggest threat}

The anti-Asian riots investigation, while inconclusive, highlighted another problem facing PNG: the incapacity of government agencies to carry out their functions effectively. Where there is a lack of law enforcement, corruption flourishes. Often, government officers collaborate and take advantage of the situation to abuse the system for bribes and favours. Many illegal activities and illicit trades are not done in secret anymore, but quite openly, as there is no longer respect for and fear of the law. An example is the smuggling of firecrackers into PNG, a product that has been banned since the 1970s. Today, firecrackers are smuggled in and openly exploded without fear of prosecution by the authorities. In many cases, police officers themselves are involved in selling the banned product.

The Manufacturers Council of PNG (MCPNG) has warned of rampant illicit trade in PNG despite steps being taken to address it. MCPNG chief executive Chey Scovell said an illicit trade taskforce has been set up by the government but has not been operational, and his biggest concern is public safety, followed by brand damage and loss of business by council members (The National 2018). PNG's popular local beer South Pacific 
was one of the products to have counterfeits imported and sold in the country, but Scovell said other products like 'biscuits, water, canned foods, bleach, detergents, soap, matches, nails, plywood, cigarettes, tea, coffee and even nails have all been counterfeited over the years' (ibid.).

The Independent Consumer and Competition Commission (ICCC) has also called on retail shops and supermarkets to stop selling counterfeit products, which it described as non-English-labelled products (Kuusa 2017). It identified a popular product in PNG, Indomie Mi Goreng noodles, had been found to have a counterfeit. ICCC commissioner and chief executive officer Paulus Ain said both products look the same except the label of the counterfeit product is not written in English but another language. The ICCC said the English labelling requirement was specific and that the ingredients, distributor, importer, country of origin and net weight needed to be in English.

Even traditional items made by Papua New Guineans have not been spared. Goods including string bags (bilum) and meri blouses have imitations produced in China and imported and sold cheaply in Chinese shops in PNG. The government has raided Chinese retail shops and confiscated and destroyed such goods. According to Commerce and Industry Minister Wera Mori, bilum weaving is a reserved activity as a cottage industry for Papua New Guineans only (Eri 2018). Popular PNG rugby league team the PNG Hunters has also had imitations of its merchandise produced and sold illegally by Chinese shops, resulting in police raids in Port Moresby confiscating and destroying some of the goods. League administrators have called on the authorities to investigate and punish shops that carry out such activities (Badui-Owa 2018).

Another illegal activity by Chinese-owned businesses is the piracy of popular local music, which has widely affected the PNG music industry. Music piracy is a global menace, and PNG has its share of complaints that Chinese shops illegally copy local music onto flash drives and sell them to the public. The practice has severely impacted the fledgling local music industry, with artists and recording studios losing out on revenue from sales of recorded music. Local artists now depend on performances to generate revenue, while recorded music is only used to promote the artist. In 2012, popular local music artist Gedix Atege took a Chinese businessman to court, accusing him of illegally selling his musical works on flash drives to customers (Safihao 2012). National Court judge David Cannings found that while there was sufficient evidence the accused 
had downloaded songs onto a flash drive and sold them, Gedix had not provided evidence to prove that the downloaded songs were in fact his musical works that he had not authorised the reproduction of; thus, the case was dismissed.

PNG's incapacity to police and protect its borders is giving smugglers of drugs, weapons and other illegal items access to the country and posing security threats to PNG and its neighbours Australia, Indonesia, New Zealand and the Pacific countries. These threats require Australian police and border security to work closely with PNG authorities to secure the borders of both countries, which has been happening for years.

\section{A challenge for investors, including the Chinese}

PNG's persisting law and order problems, together with its deteriorating infrastructure and the incapacity of the government to govern and police, will continue to be a challenge to investments in the country. Chinese and other foreign investors, whether in large-scale projects operated by multinational conglomerates or in retail industries in townships, need the guarantee of security for their operations. While big companies provide their own internal security forces that are often backed up by PNG police squads strategically located nearby, independent retailers have to make their own arrangements. Armed police officers are also assigned to investors operating in remote areas such as mining or logging companies. These officers have been known to harass and assault local people who have grievances with the companies. PNG's police force has inadequate human resources, with an ageing force that has not been sufficiently replenished and enlarged to serve the ever-growing population. Assigning officers to provide security for projects patronised by the government and politicians further weakens and undermines the rule of law in the towns and districts. The ratio of police officers to the growing PNG population is one police officer to more than 1,000 people, well above the United Nations recommended ratio of 1:450. Factors such as a lack of police accommodation, as is the case in Madang, has worsened the ratio to 1:3000 people (Shisei 2015). Chinese retailers also have to secure their investments and need to establish relationships with the police, local government officials and local people to guarantee their safety and security. Again, providing fuel money, lunch, beer or other incentives to 
the police is a common practice. In provincial towns, police officers are mandated to provide security to the businesses, and often this can extend to providing armed escorts for bank runs. A number of Chinese retailers have been killed by criminals when banking. Retailers who move into the rural areas do so at their own risk and a number have become targets from criminal elements.

The integrity of the PNG police was also seriously undermined when the former prime minister O'Neill removed successive commissioners to prevent them from arresting him following investigations into the Paraka case. Paul Paraka is a lawyer whose firm, Paul Paraka Lawyers, was alleged to have been unlawfully paid K71.8 million by O'Neill. Prime Minister Marape has taken steps to restore the force by appointing Madang MP Bryan Kramer, a critic of O'Neill seen as a key architect in engineering his downfall, as Minister for Police. Kramer's first action after taking office was to remove the police commissioner appointed by O'Neill and replace him with a younger officer, David Manning. Kramer has also vowed to keep politics out of the police force and to ensure the police follow up on and investigate the list of complaints against senior PNG leaders, including O’Neill.

The Pacific Marine Industrial Zone in Madang, a major project that was funded by China and to be developed by Chinese companies some 10 years ago, has also failed to get off the ground. The PNG Government spent K30 million (US\$9 million) on the project, but there is nothing to be seen for it except a fence covered by bushes and a gate at the site. Money from the Export-Import Bank of China was also supposed to fund the project; however, mounting opposition to the project by local people halted its development. The project was one of the things discussed by former prime minister O'Neill and President Xi Jinping when he went to sign on to the BRI. The Secretary for the Department of Commerce and Industry Andrew Liliura said that the revised Export-Import Bank of China loan will be US\$156 million (K484 million), which will be drawn down to start the project (Post-Courier 2018). The money will be used to build the fishing and container wharves. The project was originally planned to house 10 canneries and provide 30,000 jobs. 


\section{Conclusion}

PNG's development progress to achieve its Vision 2050, a national strategy for the country to become fully developed by 2050 , is not on target as its leaders envisioned. Already the country has failed to achieve any of the United Nations millennium development goals it had set (PNG Government 2015). Tensions with Chinese traders and other Chinese investments are not likely to ease in the near future as PNG struggles with its rampant corruption, chronic law and order problems and governance issues affecting the economy, politics and the delivery of services. The change of government in 2019 brings some hope that these issues will be addressed; however, it will require a huge commitment from the government and the people. PNG landowners and stakeholders involved in major investments by the Chinese and other foreign companies continue to have issues that disrupt operations and have to be addressed or dealt with by the government and the investors. As Papua New Guineans become better educated and experienced in dealing with investors, they are questioning and challenging investment agreements, including new ones being planned. Major investments planned for the country such as the Pacific Marine Industrial Zone are yet to get off the ground despite vast amounts of money already spent on them. China is seeking natural resources to feed its massive industries and offering attractive loans in return that allow it to export not only its expertise and technology but plants, equipment and labour as well. While PNG has received some attractive infrastructures that are visible evidence of development, other projects - like the K40 million (US\$12 million) sixlane boulevard to the parliament, which was appropriately dubbed the road to nowhere-are useless to the people. The reality is that people are unable to access basic government services, are dying from poor health services and drug shortages, are struggling to educate their children and are deprived of economic opportunities to support themselves. The Marape Government's reactivation of the parliamentary Public Accounts Committee began with an inquiry into the health department that revealed widespread corruption and breaches of process in the acquiring and distribution of medical drugs as well as in appointments to key positions. Institutions that are supposed to serve the people lack the capacity, with shortages of funding, human and material resources allowing corruption to spread as people desperately seek services. PNG's Catholic bishops were scathing when criticising the hosting of APEC (Asia-Pacific Economic Cooperation) in 2018, saying that all it showed was the rich getting richer while the poor were getting poorer: 
APEC seems to be a manifestation of this gap as the whole of PNG watches billions being spent on appearances in Port Moresby while we experience teachers and health workers without pay and health centres without medicine (CBC 2018).

These serious issues are creating tensions every day in PNG, and this is the reality that Chinese traders and investors are both contributing to and being impacted by. If China really wants to help PNG and Pacific countries, it should be critical about whether the aid it is giving is benefiting the people of the country or just creating white elephants. China should be more concerned about what its citizens are doing in PNG and take steps to control their movements and prevent them from breaking the laws. Vanuatu's Foreign Minister Ralph Regenvanu echoed similar sentiments when he recently warned that 'Chinese investment in the region is fuelling corruption and causing resentment among local people' (Packham 2019). Former prime minister O'Neill nurtured a close relationship with China and signed on to the BRI with promises of more Chinese funding for development, but he was forced out of power soon after. If China truly wants to make the world a better place by engaging nations through the BRI to expand trade links, it needs to show more interest in the affairs of the countries it is signing on and make sure the relationship is mutually beneficial.

\section{References}

Badui-Owa, J. 2018. Morobe Governor Warns Foreign-Owned Shops Against Selling of Fake Bilums. EMTV, 4 July. emtv.com.pg/morobe-governor-warnsforeign-owned-shops-against-selling-of-fake-bilums

Barnett, T. E. 1987. Report of the Commission of Inquiry into Aspects of the Forestry Industry. Boroko: Commission of Inquiry into Aspects of the Forest Industry.

BBC News 2013. Four Chinese Killed in Papua New Guinea Knife Attack. 26 June. www.bbc.com/news/world-asia-china-23058550

CBC (Catholic Bishops Conference of Papua New Guinea \& Solomon Islands) 2018. The Catholic Church and APEC. www.pngsicbc.com/press-release-4apec

Chin, J. 2008. Contemporary Chinese Community in Papua-New Guinea: Old Money versus New Migrants. Chinese Southern Diaspora Studies 2. chl-old.anu. edu.au/publications/csds/csds2008/117ChinCSDS2008Master.pdf 
Doherty, B. 2019. Experts Dispel Claims of China Debt-Trap Diplomacy in Pacific but Risks Remain. The Guardian, 21 October. www.theguardian. com/world/2019/oct/21/chinese-loans-expose-pacific-islands-to-risk-ofunsustainable-debt-report-finds

Eri, S. 2018. Ban on Counterfeit Bilums and Meri Blouses. EMTV, 15 August. www.emtv.com.pg/ban-on-counterfeit-bilums-and-meri-blouses/

Goldring, J.L. 1972. New Guinea Review. The Australian Quarterly 44(1):114-26.

Hernandez, A. 2009. Philippine Embassy Denies 'Aliens' Report. The National, 10 November. thenational.com.pg/philippine-embassy-denies- $\%$ E2\%80\%98 aliens\%E2\%80\%99-report/

Kenneth, G. 2019. Eoe Delivers 'Take Back PNG' Policies at UN Meet. PostCourier, 30 September. postcourier.com.pg/eoe-delivers-take-back-png-policiesat-un-meet/

Kolo, P. 2009. Bribery rampant in PNG Foreign Affairs Ministry. Pacific Islands Report. 11 June. www.pireport.org/articles/2009/11/06/bribery-rampant-pngforeign-affairs-agency

Kuusa, M. 2017. Non-English Labelled Products a Concern. Loop PNG, 31 October. www.looppng.com/png-news/non-english-labelled-productsconcern-68781

Lapmiemben v Kuso 2009. PGDC 62; DC932. 30 July. www.paclii.org/pg/cases/ PGDC/2009/62.html

Mantesso, S. 2018. Are China's Cheap Loans to Poor Nations a Development Boost or a Debt Trap? ABC News, 16 November. www.abc.net.au/news/201811-16/are-china-cheap-loans-to-poor-nations-a-debt-trap/10493286

Mihalic, F. 1971. The Jacaranda Dictionary and Grammar of Melanesian Pidgin. Port Moresby: Jacaranda.

Morauta, M. 2010. Corruption: Plenty Talk, Little Action. In W. McCarthy and W.M. McManus (eds), Inclusive Approaches to Good Governance. Madang: DWU Press, 10-15.

Ombudsman Commission 1982. Corruption in Government. Port Moresby: Ombudsman Commission.

Packham, B. 2019. China 'Fuelling Corruption, Resentment in Pacific': Vanuatu Foreign Minister. The Australian, 12 March. www.theaustralian.com.au/nation/ world/china-fuelling-corruption-resentment-in-pacific-vanuatu-foreignminister/news-story/3a616846ed88566356748b7ce3874100 
PNG Government 2015. Milennium Development Goals Final Summary Report 2015. Port Moresby: Department of National Planning and Monitoring, Government of Papua New Guinea. www.undp.org/content/dam/papua_ new_guinea/docs/015UNDP\%20PNG\%20MDG\%20Progress\%20Report_ 100216.pdf

PNG Report 2020. Madang Fish Market Reopens. 3 March. www.pngreport.com/ fisheries/news/1382031/madang-fish-market-reopens

Post-Courier 2018. Revised PMIZ Loan Confirmed at US\$156m. 13 July. postcourier.com.pg/revised-pmiz-loan-confirmed-us $156 \mathrm{~m} /$

Safihao, J. 2012. Salesman Escapes Copyright Penalty. The National, 1 April. www.thenational.com.pg/salesman-escapes-copyright-penalty/

Shisei, R. 2015. Mandang PPC: 33 New Police Recruits, Not Enough for the Province. EMTV, 25 September. www.emtv.com.pg/madang-ppc-33-newpolice-recruits-not-enough-for-the-province/

Sinclair, J. 2006. Madang. Madang: DWU Press.

Smith, G. 2014. Fuqing Dreaming: 'New' Chinese Communities in Papua New Guinea. In P. D’Arcy, P. Matbob and L. Crowl (eds), Pacific-Asia Partnerships in Resource Development. Madang: DWU Press, 232-39.

South China Morning Post 2018. 'My People Can't Compete': As China's Influence Grows in Pacific, So Does Local Resentment and International Worry. 18 June. www.scmp.com/news/asia/southeast-asia/article/2151217/my-people-cantcompete-chinas-influence-grows-pacific-so

Tannos, J. and S. Eroro 2009. Asian Riot Probe Team Members Step Down in Protest. Post-Courier, 26 November.

Taylor, M. 2019. The China Alternative: Changing Regional Order in the Pacific Islands. Keynote address at the University of the South Pacific, Port Vila, Vanuatu, 8 February. www.forumsec.org/keynote-address-by-dame-megtaylor-secretary-general-the-china-alternative-changing-regional-order-inthe-pacific-islands/

The National 2018. Rise in Illicit Trade Upsets Council. 17 December. www.the national.com.pg/rise-in-illicit-trade-upsets-council/

Tlozec, E. 2018. Chinese Businessman Charged with Bribery in Papua New Guinea over Immigration Scheme. ABC News, 17 May. www.abc.net.au/news/201805-07/chinese-businessman-charged-with-attempted-bribery-in-png/9733708

Wani, D. 2018. Illegal Group Exists. The National, 12 February. www.thenational. com.pg/illegal-group-exists/ 
This text is taken from The China Alternative: Changing Regional Order in the Pacific Islands, edited by Graeme Smith and Terence Wesley-Smith, published 2021 by ANU Press, The Australian National University, Canberra, Australia.

doi.org/10.22459/CA.2021.15 